\title{
Erratum zu: Fallbeschreibung und Ergebnisse
}

\section{Erratum zu:}

\section{Kapitel 8 in: N. Bernhardsson-Laros, Wertehorizont Beschäf- tigungsfähigkeit im Betrieb, https://doi.org/10.1007/978-3-658-19747-6_8}

Die Abbildung 3 auf S. 199 wurde verlagsseitig falsch bearbeitet und wurde daher ausgetauscht.

Die aktualisierte Originalversion des Kapitels kann hier abgerufen werden https://doi.org/10.1007/978-3-658-19747-6_8 


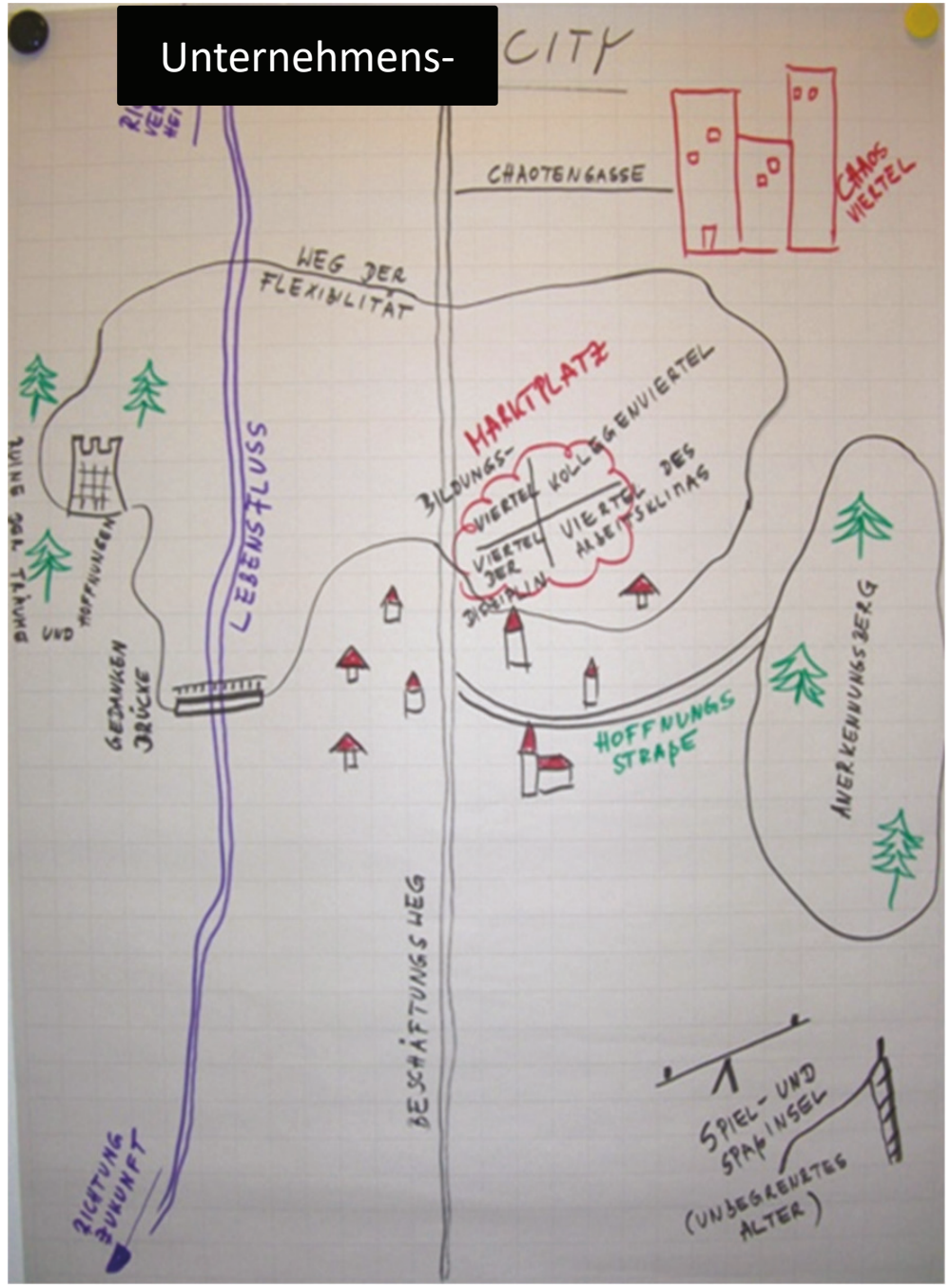

Abbildung 3: Landkarte AG2: Unternehmens-City 